\title{
STATE CONSENT TO THE PROVISION OF HUMANITARIAN ASSISTANCE IN NON-INTERNATIONAL ARMED CONFLICTS
}

\begin{abstract}
JESSICA SCHAFFER*
In light of repeated denials and obstruction of relief efforts by belligerent states, particularly when directed towards non-state armed groups designated as terrorist groups or justified as a legitimate response to the COVID-19 pandemic, this article provides a comprehensive analysis of the international legal position regarding the provision of humanitarian assistance in non-international armed conflicts. The article argues that although a general right of access has not crystalised, relief operations into territory under the effective control of a non-state armed group without state consent may be permissible with Security Council authorisation or otherwise, in appropriate circumstances, under the rules of state responsibility. More broadly, belligerent parties must abide by their legal obligations to ensure that the needs of civilians are met.
\end{abstract}

\section{INTRODUCTION}

The Office for the Coordination of Humanitarian Affairs estimated that nearly 168 million people would need humanitarian assistance in 2020, with the key driver for humanitarian needs being armed conflict. ${ }^{1}$ The lack of essential goods and services during armed conflict aggravates the suffering inflicted by war and contributes to the forced displacement of millions of people. It is therefore critical that rapid, unimpeded and sustained humanitarian assistance is available to alleviate the effects of armed conflict. The belligerent state has the responsibility to provide for the basic needs of its civilian population or, where it is unable to do so, to allow and facilitate the provision of humanitarian assistance in its territory. However, the changing nature of warfare from international to non-international armed conflict and the proliferation of non-state armed groups have created new

PhD candidate, Faculty of Law, Bond University. This paper is an updated version of the author's thesis submitted as part of her LLM at Leiden University. The author wishes to thank Dr Robert Heinsch (Leiden University) for his guidance and comments.

Office for the Coordination of Humanitarian Affairs ('OCHA'), Global Humanitarian Overview 2020 (10 December 2019) 4, 11-12, 25. See also Report of the Secretary-General on the Protection of Civilians in Armed Conflict, UN Doc S/2020/366 (6 May 2020) 6 ('Report of the Secretary-General 2020'). 
and complicated challenges regarding the provision and delivery of humanitarian assistance.

Where states are facing an internal enemy they are more likely to rely on arguments of territorial sovereignty to deny access to civilians under the control of non-state armed groups, or to otherwise interfere with aid operations through direct attacks on humanitarian personnel, the use of siege and starvation as a weapon of war, or by blocking or imposing onerous restrictions on the transit of humanitarian supplies and personnel. ${ }^{2}$ In 2019, the United Nations ('UN') Secretary-General reported widespread incidents of violence, harassment and arbitrary detention against humanitarian personnel and assets, including 535 incidents of violence against aid workers in South Sudan and 392 incidents in Yemen, as well as copious bureaucratic impediments to access causing severe delays in the provision of humanitarian services - for example, the arbitrary taxation of humanitarian workers in Somalia, and complex registration and visa processes in the Democratic Republic of Congo. ${ }^{3}$

Humanitarian operations have also been constrained by counter-terrorism frameworks as governments impose restrictions on funding, hampering the ability of humanitarian groups to provide assistance to civilians under the control of armed groups labeled 'terrorists'. This has significantly curtailed the abilities of relief societies to carry out necessary humanitarian work. 4 The COVID-19 pandemic has further compounded existing humanitarian challenges as measures by states to contain its spread, such as restrictions on international travel, border closures and lockdowns, have impacted the ability of humanitarian organisations to operate and of populations to access aid. ${ }^{5}$ Furthermore, states have exploited the pandemic by adopting regressive measures disguised as emergency health measures aimed at curtailing access. ${ }^{6}$ For example, restrictions and bureaucratic obstacles with respect to aid deliveries in Syria are preventing

\footnotetext{
Government of Switzerland, Humanitarian Access in Situations of Armed Conflict: Handbook on the Normative Framework (Version 1, 31 December 2011) 10 ('Handbook on the Normative Framework'); OCHA (n 1) 14 .

Report of the Secretary-General 2020 (n 1) 5-6.

Jessica S Burniske and Naz K Modirzadeh, Pilot Empirical Survey Study on the Impact of Counterterrorism Measures on Humanitarian Action and Comment (Harvard Law School Program on International Law and Armed Conflict, March 2017) 7 <http://blogs.harvard.edu/pilac/files/2017/ 03/Pilot-Empirical-Survey-Study-and-Comment-2017.pdf $>$.

ACAPS, Crisis in Sight Humanitarian Access Overview: A Snapshot of the Most Challenging Contexts (Report, 13 July 2020) 8-9.

Covid 19 Pandemic Amplifying, Exploiting World's Fragilities, Secretary-General Tells Security Council Debate on Protecting Civilians in Armed Conflict, UN Doc SC/14196 (27 May 2020) ('UN Covid-19 Press Release').
} 
medical supplies, equipment and personnel from reaching those in need, ${ }^{7}$ while suspensions of flights, curfews and lockdown regulations have significantly constrained and delayed humanitarian access in Libya during the pandemic. ${ }^{8}$

This article will comprehensively analyse the extent to which a state's sovereignty can be reconciled with the humanitarian imperative to alleviate suffering and the right of the civilian population to receive humanitarian aid. While victims of non-international armed conflicts have a right to humanitarian assistance, this is difficult to enforce, as a general right of access allowing for unilateral relief operations into opposition-held territory without state consent has not crystalised in international law. Rather, this article advocates that relief operations into territory under the effective control of a non-state armed group operating without state consent may be permissible where the Security Council provides authorisation, or otherwise under the doctrine of necessity or as a countermeasure where the necessary criteria are met. While these provide limited opportunities to circumvent state consent, this article highlights the gaps in international humanitarian law in enforcing the right of civilians to receive essential supplies and reinforces the imperative that belligerent parties abide by their legal obligations to ensure that the needs of civilians are adequately met.

\section{The Legal Framework Governing Humanitarian Assistance iN NON-INTERNATIONAL ARMED CONFLICTS}

The term 'humanitarian assistance' is not defined in public international law and has no commonly accepted meaning in practice. The UN General Assembly has referred to humanitarian assistance as including 'medicines, non-perishable food stuffs, blankets, tents and clothing'. ${ }^{9}$ The International Court of Justice ('ICJ') has determined that, in reference to the United States' legislative definition of humanitarian assistance as including the provision of food, clothing, medicine and other humanitarian assistance, it did not include the provision of weapons, ammunition or other equipment that could inflict serious bodily harm or death. ${ }^{10}$ The International Committee of the Red Cross ('ICRC') has used the

\footnotetext{
Human Rights Watch, 'Syria: Aid Restrictions Hinder Covid-19 Response' (Human Rights Watch, 28 April 2020) <https://www.hrw.org/news/2020/04/28/syria-aid-restrictions-hinder-covid19-response >.

OCHA, 'Libya: Humanitarian Access Situation Report No 2' (April 2020) <https://www. humanitarianresponse.info/sites/www.humanitarianresponse.info/files/documents/files/access _report___april_2020.pdf>.

GA Res 2717 (XXV), UN Doc A/Res/2717 (15 December 1970) [5(c)].

Case Concerning Military and Paramilitary Activities in and against Nicaragua (Nicaragua v United States of America) (Merits) [1986] ICJ 14, 47 [97] ('Nicaragua').
} 
term 'humanitarian activities' in the context of an armed conflict to mean goods that 'seek to preserve the life, security, dignity and physical and mental wellbeing of persons affected by the conflict, or which seek to restore the said wellbeing if it has been infringed upon' . ${ }^{11}$ In light of the above, the term 'humanitarian assistance' will be used here to mean the provision of goods and services essential to the survival of the civilian population, which are urgently needed and exclusively humanitarian in nature..$^{12}$ It may comprise material aid such as food, water, medical supplies, clothing, shelter and associated logistics, as well as the services of trained personnel. 'Humanitarian access', on the other hand, refers to both the capacity of humanitarian actors to reach people in need and the ability of those affected to access the necessary assistance and services. ${ }^{13}$ Humanitarian access is the precondition for the effective delivery of humanitarian assistance, without which the latter would not be possible. ${ }^{14}$

\section{A Humanitarian Principles}

For assistance to be humanitarian it must be provided solely to assist civilians in need and accord with the principles of humanity, impartiality and neutrality..$^{15}$ These principles are derived from the Statutes of the International Red Cross and Red Crescent Movement ${ }^{16}$ and have been reiterated by the $\mathrm{UN}^{17}$ and other humanitarian actors $^{18}$ as providing the foundation for humanitarian action. When these principles are respected, relief action 'cannot be regarded as an unlawful

11 ICRC, 'Q\&A and Lexicon on Humanitarian Access' (2014) 96(893) International Review of the Red Cross 359, 367.

12 Emilie Ellen Kuijt, Humanitarian Assistance and State Sovereignty in International Law: Towards a Comprehensive Framework (Intersentia, 2015) 37; ICRC, 'International Humanitarian Law and the Challenges of Contemporary Armed Conflict' ( $32^{\text {nd }}$ International Conference of the Red Cross and Red Crescent, Geneva, 8-10 December 2015) 28 ('ICRC Conference 2015'); Heike Spieker, 'Humanitarian Assistance, Access in Armed Conflict and Occupation', Max Planck Encyclopedia of Public International Law (March 2013) <http://opil.ouplaw.com/view/10.1093/law:epil/ 9780199231690/law-9780199231690-e1701? rskey=YYEb28\&result=1\&prd=EPIL >.

13 Handbook on the Normative Framework (n 2) 13.

14 Ibid; Felix Schwendimann, 'The Legal Framework of Humanitarian Access in Armed Conflict' (2011) 93(884) International Review of the Red Cross 993, 993-4.

15 The Geneva Conventions of 1949 and Additional Protocols of 1977 refer to relief actions that are of an 'exclusively humanitarian and impartial nature'.

16 Statutes of the International Red Cross and Red Crescent Movement (adopted by the $25^{\text {th }}$ International Conference of the Red Cross at Geneva in 1986, amended in 1995 and 2006) art 5(2)(a) <https://www.icrc.org/en/doc/assets/files/other/statutes-en-a5.pdf>.

17 GA Res 46/182, UN Doc A/RES/46/182 (19 December 1991) [2]. This was reaffirmed in GA Res 58/114, UN Doc A/Res/58/114 (5 February 2004) Preamble. See also SC Res 1894, UN Doc S/RES/1894 (11 November 2009) [13].

18 These principles are also enshrined in the statutes of many Non-Governmental Organisations. 
intervention, or as in any other way contrary to international law' ${ }^{19}$ However, where they are not met, the aid will cease to be humanitarian. ${ }^{20}$ Impartiality means that humanitarian assistance must be provided in accordance with need, with 'no discrimination as to nationality, race, religious beliefs, class or political opinions' ${ }^{21}$ Priority is only to be given to the most urgent cases. ${ }^{22}$ The principle of humanity aims to prevent and alleviate human suffering wherever it is found, to protect life and health and ensure that the dignity and rights of all victims are respected. ${ }^{23}$ Neutrality requires that assistance be provided without the provider taking sides or engaging in hostilities. ${ }^{24}$

While there is no specific requirement in treaty law that assistance must be provided to both sides of an non-international armed conflict, ${ }^{25}$ the ICJ in Nicaragua stated that for aid to be considered humanitarian it must be given without any form of discrimination 'to all those in need'. ${ }^{26}$ This requirement is controversial and there is no general consensus that it reflects customary international law. ${ }^{27}$ Subsequent international practice, particularly of national humanitarian relief societies, as well as of states, has challenged the ICJ's interpretation that assistance must be provided to both sides in a noninternational armed conflict. ${ }^{28}$ It has instead been suggested that the humanitarian sector as a whole should aim for resulting impartially, rather than obliging each actor to fulfill this requirement itself. ${ }^{29}$ This will ensure that the principle of impartiality is respected and the needs of all civilians are met, while not demanding that each actor provide assistance to both sides. While this is not reflective of current customary international law, it is not necessarily in conflict with a broad interpretation of the ICJ's reasoning above. Where a humanitarian

Nicaragua (n 10) 114-15 [242].

Where a state seeks to provide humanitarian assistance without respecting the aforementioned principles, it may also constitute a breach of the principle of non-intervention: see Nicaragua (n 10) 115 [243].

21 Statutes of the International Red Cross and Red Crescent Movement (n 16) Preamble; ICRC, Commentary on the First Geneva Convention: Convention (I) for the Amelioration of the Condition of the Wounded and Sick in Armed Forces in the Field (Cambridge University Press, $2^{\text {nd }}$ ed, 2016) $794<$ https://ihldatabases.icrc.org/ihl/full/GCI-commentary> ('Commentary on the First Geneva Convention 2016'); Nicaragua (n 10) 114-15 [242].

Statutes of the International Red Cross and Red Crescent Movements (n 16) Preamble; Jean Pictet 'The Fundamental Principles of the Red Cross (III)' (1979) 19(212) International Review of the Red Cross 255, 257. Statutes of the International Red Cross and Red Crescent Movements (n 16) Preamble. Ibid.

Ruth Abril Stoffels, 'Legal Regulation of Humanitarian Assistance in Armed Conflict: Achievements and Gaps' (2004) 86(855) International Review of the Red Cross 537, 541. Nicaragua (n 10) 115 [243].

Kuijt (n 12) 42.

Stoffels (n 25) 541; Kate Mackintosh, The Principles of Humanitarian Action in International Humanitarian Law (Humanitarian Policy Group Report No 5, March 2000) 7-8.

29 Stoffels (n 25) 541. 
actor provides aid to one party to conceal its involvement in the latter's internal affairs, provides material support or otherwise influences the outcome of the conflict, the provision of aid will not meet the humanitarian principles and the operation will not be afforded protection under international humanitarian law. However, where the purpose of the aid is strictly to prevent and relieve human suffering, and offers of relief are affected by, for example, operational matters rather than political or military considerations or, alternatively, one side is in greater need, the humanitarian principles will arguably be met regardless of whether relief is provided to one party only. ${ }^{30}$

\section{B Treaty and Customary Law Framework}

International humanitarian law distinguishes between a non-international armed conflict within the meaning of Common Article 3 to the Geneva Conventions of 1949 and a non-international armed conflict falling within the definition in Article 1 of Additional Protocol II of 1977 ('AP II'). Common Article 3 is applicable to all non-international armed conflicts. ${ }^{31}$ AP II is only applicable to armed conflicts taking place on the territory of a state party between the armed forces of the state and a non-state armed group. ${ }^{32}$ Where a state has not ratified AP II, Common Article 3 remains the minimum applicable standard. 33

No explicit rights or duties relating to humanitarian assistance are contained in Common Article 3. Rather, subpara (1) requires at a minimum that all 'persons taking no active part in the hostilities must be treated humanely without any adverse distinction'. This is applicable in all circumstances, binding on all parties to the conflict, and military necessity cannot be invoked to justify noncompliance. ${ }^{34}$ Humane treatment is not defined; rather, it has been interpreted through state practice to mean treatment that respects a person's inherent dignity as a human being, including, but not limited to, items essential for survival, such as the provision of adequate food and drinking water, clothing, safeguards for health and hygiene, and the provision of suitable medical care. ${ }^{35}$

Mackintosh (n 28) 7-8; Kuijt (n 12) 42; Nicholas Leader, 'The Politics of Principle: The Principles of Humanitarian Action in Practice' (Humanitarian Policy Group Report No 2, March 2000) 20. For an armed conflict to fall within Common Article 3, the non-state armed group must first demonstrate a certain level of organisation; and, secondly, the hostilities must reach a minimum level of intensity: Prosecutor $v$ Tadic (Opinion and Judgment) (International Criminal Tribunal for the Former Yugoslavia, Trial Chamber, Case No IT-94-1-T, 7 May 1997) 193-94 [562].

For AP II to apply, the non-state armed group must exercise such territorial control 'as to enable them to carry out sustained and concerted military operations and to implement this Protocol': AP II, art 1(1).

Commentary on the First Geneva Convention 2016 (n 21) 564.

Ibid $560-1$.

Ibid $557-8$ 
The failure to take all reasonable measures to provide the aforementioned items, as well as the denial of the provision of such items by an external third party, could therefore amount to inhumane treatment within the meaning of Common Article $3 .^{36}$ Subparagraph (2) of Common Article 3 establishes the right of impartial humanitarian organisations to offer their services (including the provision of humanitarian relief) to all parties to a non-international armed conflict. The ICRC is explicitly mentioned as an example of an entity entitled to rely on this provision. The provision recognises not only the state, but also the non-state armed group as a potential receiver of such an offer. ${ }^{37}$ However, an offer of service to a non-state armed group does not constitute recognition of or support for the group under international law; ${ }^{38}$ nor can it be considered as an unfriendly act or unlawful interference in the domestic affairs of the state. ${ }^{39}$

Article 18 of AP II expands the regime under Common Article 3 and sets out the principles upon which relief actions are to be based. Article 18(1) deals with humanitarian assistance from within the territory of the belligerent state and confirms the right of 'relief societies located in the territory', such as the Red Cross and Red Crescent, to offer their services..$^{40}$ Article 18(2) allows for the provision of international relief actions by the ICRC or other humanitarian organisations where the responsible party can no longer meet the basic needs of the civilian population. The provision of external relief is complementary and limited to circumstances where 'the civilian population is suffering undue hardship owing to a lack of supplies essential for its survival'. ${ }^{41}$

In addition to the provisions laid down in treaty law, the ICRC has identified some obligations as having crystalised into customary international law applying in international and non-international conflicts. 42 These norms are specifically significant in non-international armed conflicts, particularly where the state has not ratified AP II. The relevant customary international law rules oblige parties,

\section{Ibid 593.}

Although non-state armed groups cannot become parties to Common Article 3, it is binding on them, both as treaty and customary law: Commentary on the First Geneva Convention 2016 (n 21) 505. Article 3(4) Common to the four Geneva Conventions of 1949: 'The application of the preceding provisions shall not affect the legal status of the Parties to the conflict.'

Commentary on the First Geneva Convention 2016 (n 21) 804; Nicaragua (n 10) 114-5 [242].

Yves Sandoz, Christophe Swinarski and Bruno Zimmermann (eds), Commentary on the Additional Protocols of 8 June 1977 to the Geneva Conventions of 12 August 1949 (ICRC/Martinus Nijhoff Publishers, 1987) 4871-2.

Ibid 4878.

Jean-Marie Henckaerts and Louise Doswald-Beck (eds), Customary International Humanitarian Law Volume I: Rules (ICRC/Cambridge University Press, 2005) ('ICRC Customary Law Study'). For criticisms of the methodology and evidence used to ascertain and support the rules, see, eg, John B Bellinger III and William J Haynes II, 'A US Government Response to the International Committee of the Red Cross Study Customary International Humanitarian Law' (2007) 89(866) International Review of the Red Cross 443, and Elizabeth Wilmshurst and Susan Breau (eds), Perspectives on the ICRC Study on Customary International Humanitarian Law (Cambridge University Press, 2007). 
once relief action has been agreed to, to allow and facilitate the rapid and unimpeded passage of humanitarian relief, ${ }^{43}$ ensure the freedom of movement of humanitarian relief personnel,44 and respect and protect personnel and objects used in humanitarian relief. 45

\section{CONSENT To Humanitarian AsSistance IN NON-INTERNATIONAL ARMED CONFLICTS}

While impartial humanitarian organisations have a right to offer humanitarian assistance, it is subject to state consent. ${ }^{46}$ The requirement of consent is explicitly mentioned in Article 18(2) of AP II and in the commentary to Common Article 3. Rule 55 of the ICRC Customary Law Study likewise clarifies that access remains subject to consent in both international and non-international armed conflicts. ${ }^{47}$ Common Article 3 is silent with respect to which party's consent is required, and it is unclear whether the humanitarian organisation must obtain the consent of both parties or whether the party to whom the offer is made can consent unilaterally. This ambiguity raises the argument that where relief operations are intended for civilians in areas under the effective control of a non-state armed group and aid can be delivered without the need to transit through territory under the state's control, the consent of the former is sufficient and it is not necessary for the humanitarian organisation to also secure the state's consent. $4^{8}$ This question is particularly pertinent where the state refuses to consent to relief operations intended for citizens in opposition-controlled areas who would otherwise be without essential supplies. Notwithstanding this omission, it seems unlikely that the drafters of Common Article 3 would have intended to breach the state's territorial sovereignty by implication, as the principle of sovereign equality is fundamental in international law. ${ }^{49}$ The silence in this provision

49 Corfu Channel Case (UK v Albania) (Merits) [1949] ICJ Rep 4, 35: 'Between independent States,

territorial sovereignty is an essential foundation of international relations.'

ICRC Customary Law Study (n 42) 193-200, r 55.

Ibid 200-2, r 56 .

Ibid 105-11, rr 31 and 32. Cf Bellinger and Haynes (n 42) 454: 'The United States does not believe Rule 31, as drafted, reflects customary international law applicable to international or noninternational armed conflicts.'

Commentary on the First Geneva Convention 2016 (n 21) 828; ICRC Conference 2015 (n 12) 28.

ICRC Customary Law Study (n 42) 197.

Marco Sassoli, 'When are States and Armed Groups Obliged to Accept Humanitarian Assistance?' (International Association of Professionals in Humanitarian Assistance and Protection, 5 November 2013); Payam Akhavan et al, 'There Is No Legal Barrier for UN Cross Border Operations in Syria' (The Guardian, 28 April 2014) <https://www.theguardian.com/world/2014/apr/28/no-legalbarrier-un-cross-border-syria>; Francoise Bouchet-Saulnier, 'Consent to Humanitarian Access: An Obligation Triggered by Territorial Control, Not States' Rights' (2014) 96 (893) International Review of the Red Cross 207, 211. 
therefore suggests that the state's consent is prima facie necessary even when assistance is provided to civilians in territory that it no longer controls. ${ }^{50}$

Article 18(2) of AP II is more explicit and refers to the consent of the 'High Contracting Party concerned', which, according to the Commentary to the Additional Protocols, means the government in power. ${ }^{51}$ Again, it has been argued that the requirement of state consent in AP II could be bypassed where relief operations are not required to transit through state-held territory, as the state party is no longer 'concerned' within the meaning of Article 18(2). ${ }^{52}$ Such a reading implies a negation of the state's territorial sovereignty and it is again unlikely that states would have agreed at the time of drafting to be placed on the same footing as the party seeking to overthrow it. This was the stance taken by states at the Diplomatic Conference that adopted the two Additional Protocols.53 Furthermore, while a non-state armed group may be 'concerned' with any relief operations carried out in territory under its control, it cannot be a party to AP II. As such, if the consent of the state is unnecessary, it leaves no High Contracting Party concerned, making the express reference to such a requirement redundant. In light of the silence of Common Article 3 and the specific reference to 'the High Contracting Party' in Article 18(2) AP II, as well as the primacy of state sovereignty in public international law, it is difficult to see how the consent of the state can be bypassed without such an interpretation conflicting with a strict reading of the necessary provisions. This remains the position of the ICRC. 54

In practice, it is generally crucial that, in addition to obtaining state consent, humanitarian organisations also obtain the consent of the non-state armed group to ensure that aid is delivered safely into its territory. ${ }^{55}$ Whether it is a legal requirement to obtain their consent rather than just a practical necessity is unclear given the silence in the Geneva Conventions. However, as Common Article 3 does not privilege the High Contracting Party and binds all 'parties to the conflict', it would be paradoxical to impose obligations upon non-state actors while simultaneously undertaking action in territory under their control without

Commentary on the First Geneva Convention 2016 (n 21) 828. This is the position of the ICRC; see ICRC Conference 2015 (n 12) 28.

$51 \quad$ Sandoz et al (n 40) 4884. See also Denise Plattner, 'Assistance to the Civilian Population: The Development and Present State of International Humanitarian Law' (1992) 32(288) International Review of the Red Cross <https://www.icrc.org/en/doc/resources/documents/article/other/57jmar. htm>; Frits Kalshoven and Liesbeth Zegveld, Constraints on the Waging of War: An Introduction to International Humanitarian Law (Cambridge University Press, $4^{\text {th }}$ ed, 2011) 150. Michael Bothe et al, New Rules for Victims of Armed Conflicts: Commentary on the Two 1977 Protocols Additional to the Geneva Conventions of 1949 (Martinus Nijhoff, $2^{\text {nd }}$ ed, 2013) 801. Stoffels (n 25) 535 .

ICRC, 'Q\&A and Lexicon on Humanitarian Access' (n 11) 363.

ICRC Conference 2015 (n 12) 28; Emanuela-Chiara Gillard, 'The Law Regulating Cross-Border Relief Operations' (2013) 95(890) International Review of the Red Cross 363, 367; Sandesh Sivakumaran, The Law of Non-International Armed Conflicts (Oxford University Press, 2012) 332. 
their consent. Furthermore, there is a growing acceptance in public international law in general and international humanitarian law specifically that non-state actors exerting control over territory or using armed force have responsibilities under international law..$^{6}$ This is demonstrated by an increasing number of UN Security Council resolutions on the protection of civilians in armed conflict which demand that all parties to the conflict abide by their obligations to respect and facilitate relief operations. ${ }^{57}$ As such, the consent of the non-state armed group should be sought as both a practical and legal requirement.

Where an impartial humanitarian actor makes an offer of assistance, a state is not obliged to agree unconditionally to the offer. First, the state must be unable or unwilling to fulfill its primary obligations to the civilian population..$^{58}$ Where a state is able to respond to the humanitarian needs of its civilians or has accepted an offer from elsewhere, a failure to consent will not breach its obligations. ${ }^{59}$ Secondly, offers must meet the preliminary conditions imposed by international humanitarian law to avoid violating the principle of non-intervention. ${ }^{60}$ Where offers are not exclusively humanitarian, impartial or otherwise carried out in a non-principled manner, states may legitimately refuse consent. ${ }^{61}$ Thirdly, the provision of humanitarian assistance may be temporarily restricted for reasons of military necessity, for example where the presence of humanitarian actors would interfere with a military operation or, alternatively, if the safety of humanitarian personnel cannot be guaranteed. ${ }^{62}$ However, military necessity is not a permissible ground to refuse a valid offer of service in its entirety. ${ }^{63}$ Rather, a refusal to provide access must be strictly necessary and proportionate to achieve the aforementioned aims and any restrictions must be implemented for only as long as the relevant security conditions prevail. ${ }^{64}$ Outside these parameters, the fact that consent must be sought does not mean that it is discretionary. ${ }^{65}$ The requirement of consent should be read in conjunction with the dual responsibility

Dapo Akande and Emanuela-Chiara Gillard, Oxford Guidance on the Law Relating to Humanitarian Relief Operations in Situations of Armed Conflict (UNOCHA, 2016) 13.

See, eg, SC Res 1894 (n 17) [14]; SC Res 1923, UN Doc S/RES/1923 (25 May 2010) [22]; SC Res 2191, UN Doc S/RES/2191 (17 December 2014) Preamble, [1]; Bouchet-Saulnier (n 48) 211-2.

Sandoz et al (n 40) 4871.

Commentary on the First Geneva Convention 2016 (n 21) 834; ICRC Conference 2015 (n 12) 29.

Schwendimann (n 14) 997; Nicaragua (n 10) 124-5 [242]-[243].

ICRC Conference 2015 (n 12) 29; Akande and Gillard (n 56) 21.

ICRC Customary Law Study (n 42) 202, r 56; Commentary on the First Geneva Convention 2016 (n 21) 839; Cedric Ryngaert, 'Humanitarian Assistance and the Conundrum of Consent: A Legal Perspective' (2013) 5(2) Amsterdam Law Forum 5, 9.

ICRC Customary Law Study (n 42) 202; Commentary on the First Geneva Convention 2016 (n 21) 838.

Akande and Gillard (n 56) 24; ICRC, 'Q\&A and Lexicon on Humanitarian Access' (n 11) 364.

Bothe (n 52) 800-1; Sandoz et al (n 40) 4885. This can also be distilled from the words 'shall be undertaken' in AP II, art 18(2), which suggests that the right of the state to withhold consent is necessarily constrained. 
of the state to treat its civilian population humanely, as well as its obligations to take positive actions in fulfillment of the rights to life, food and health. ${ }^{66}$ These concurrent obligations necessarily limit states' abilities to exercise their right of control.

\section{A Security Council Resolutions and State Consent}

States have no latitude to withhold consent to humanitarian relief operations where the Security Council has adopted a binding decision. ${ }^{67}$ In 2014, the Security Council passed Resolution 2165 in response to the Syrian government's failure to allow the safe passage of humanitarian assistance. ${ }^{68}$ This resolution authorised UN humanitarian agencies and their partners to deliver assistance through four designated cross points in Turkey to populations in opposition-held areas without the consent of the Syrian government. ${ }^{69}$ This was extended annually by the Secuirty Council until 2020 when a resolution seeking to extend the operation of the cross-border mechanism for a further 12 months failed. ${ }^{70}$

While the Security Council did not explicitly invoke its powers under Chapter VII of the UNCharter when it adopted Resolution 2165, there are reasons to suggest that it was nonetheless acting under Chapter VII. ${ }^{71}$ First, the legally binding nature of the resolution can be derived from its specific reference to Article 25 of the Charter, ${ }^{72}$ which obliges member states to carry out Security Council decisions. ${ }^{73}$ Secondly, the wording of the resolution indicates its binding nature.74 Previous resolutions with respect to the Syrian conflict were expressed in honorary terms, urging the parties to comply with their obligations under international humanitarian law. ${ }^{75}$ In contrast, Resolution 2165 demanded that the parties to the conflict comply with the operative provisions of the resolution and cooperate with

Kuijt (n 12) 356-7; ICRC, 'Q\&A and Lexicon on Humanitarian Access' (n 11) 369.

Akande and Gillard (n 56) 18; Yoram Dinstein, 'The Right to Humanitarian Assistance' (2000) 53(4) Naval War College Review 77, 86.

SC Res 2165, UN Doc S/RES/2165 (14 July 2014).

Ibid [2].

See In Two Separate Votes, Security Council Fails to Adopt Resolutions Extending Cross-Border Mechanism for Humanitarian Aid Delivery into Syria (Press Release, 10 July 2020) UN Doc SC/14246. Andreas Zimmermann, 'Humanitarian Assistance and the Security Council' (2017) 50(1) Israel Law Review 3, 11-14.

SC Res 2165 (n 68) Preamble.

Legal Consequences for States of the Continued Presence of South Africa in Namibia (South West Africa) notwithstanding Security Council Resolution 276 [1971] (Advisory Opinion) ICJ Rep 16, 53 [113].

Ibid 53 [114].

Zimmermann (n 71) 5-6. See, eg, SC Res 688, UN Doc S/RES/688 (5 April 1991) [3]; SC Res 752, UN Doc S/RES/752 (5 May 1992) [8]; SC Res 794, UN Doc S/RES/794 (3 December 1992) [2]-[3]; SC Res 2042, UN Doc S/RES/2042 (14 April 2012) [10]. 
UN agencies and their operating partners to facilitate humanitarian access. ${ }^{76}$ Lastly, the resolution committed the Security Council to adopting further measures in the event of non-compliance. 77 This implies that it had already taken binding measures when it adopted Resolution $2165 . .^{78}$ In light of the above, and as a result of the binding nature of the resolution, the legal position of the parties to the conflict was altered and it was no longer within Syria's discretion to consent.79

\section{B Where Withholding Consent Violates a State's Obligations under International Law}

Despite the absence of specific words in AP II, sufficient state practice has arisen to establish a rule whereby a party cannot arbitrarily withhold their consent to relief operations. ${ }^{80}$ The UN Security Council has clarified that the arbitrary denial of humanitarian access could constitute a violation of international humanitarian law. ${ }^{81}$ This has been repeated in resolutions of the UN General Assembly, the UN Human Rights Council and the UN Secretary-General. ${ }^{82}$ It is also recognised as a rule of customary international law. ${ }^{83}$ However, there is no formal definition or guidance in international humanitarian law as to how the criteria of arbitrariness should be interpreted, and its use, in the context of international humanitarian law, has not been addressed by an international or national tribunal. As such, guidance as to what conduct would be arbitrary is drawn from international human rights law ${ }^{84}$ and subsequent state practice. ${ }^{85}$

The withholding of consent will be arbitrary where it violates a state's obligations under, or otherwise seeks an objective contrary to, international humanitarian law. ${ }^{86}$ Circumstances include the use of starvation against the civilian population as a method of warfare in violation of Article 14 of AP $\mathrm{II}^{87}$ or a

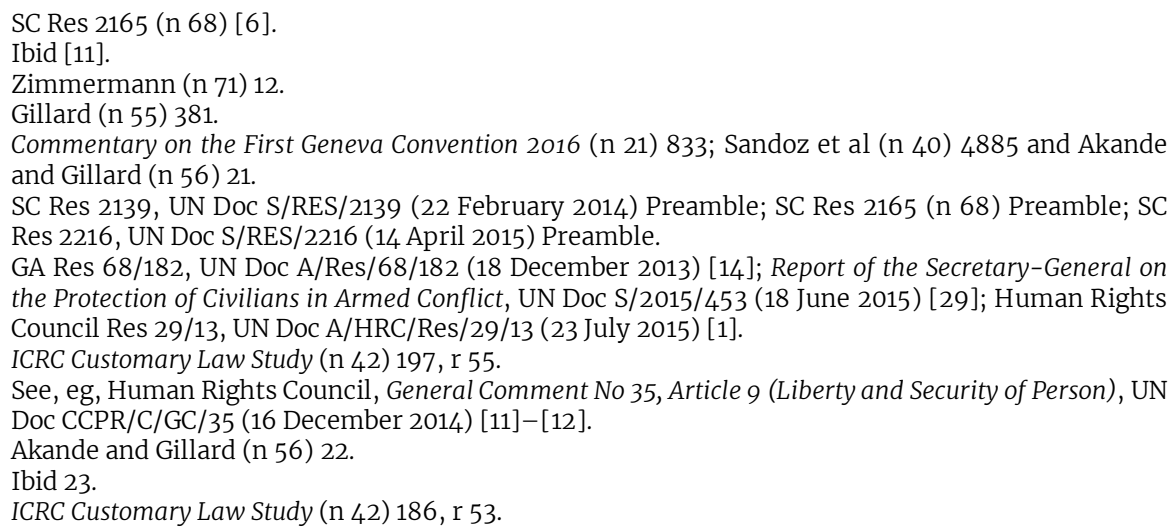


failure to provide civilians with sufficient food or medical care in contravention of the prohibition of violence to life and person contained in Common Article $3 .{ }^{88} \mathrm{As}$ such, where a humanitarian organisation makes an offer of assistance, a denial of access intending to or which could forseeably cause the starvation of the civilian population will be arbitrary and the state is required to give consent. ${ }^{89}$ Additionally, withholding consent to punish the civilian population would violate the prohibition on collective punishment and would be arbitrary..$^{90}$ Similarly, withholding consent for the purpose of discriminating against a particular ethnic or racial group would be arbitrary, as it would violate the prohibition to treat the civilian population without adverse distinction. ${ }^{91}$ Lastly, a failure to treat the wounded and sick humanely ${ }^{92}$ and provide access for medical personnel and supplies ${ }^{93}$ would amount to a violation of Common Article 3(1) and Article 7 of AP II and would be arbitrary. ${ }^{94}$

\section{The Impact of Counter-Terrorism Legislation on Impartial Humanitarian Action}

In attempts to suppress the commission of international terrorism, the UN Security Council has passed a number of resolutions obliging member states to implement domestic measures aimed at curtailing the provision of financial and material support to terrorist groups. ${ }^{95}$ These obligations have been broadly defined and the ensuing domestic counter-terrorism measures enacted by UN member states have the potential to include activities of humanitarian actors engaged in principled humanitarian action. ${ }^{96}$ This creates obstacles with respect to the delivery of principled humanitarian aid to civilians under the effective control of a non-state armed group designated as a terrorist group. ${ }^{97}$

Commentary on the First Geneva Convention 2016 (n 21) 593, 599.

Ibid 836; Sandoz et al (n 40) 4885; ICRC Customary Law Study (n 42) 197.

AP II, art 4(2)(b); ICRC Customary Law Study (n 42) 379, r 103.

AP II, art 4(1); Common Article 3; ICRC Customary Law Study (n 42) 308, r 88.

AP II, art 7; Common Article 3(1) and (2).

ICRC Customary Law Study (n 42) 400, r 110.

Ibid 402.

SC Res 1267, UN Doc S/RES/1267 (15 October 1999); SC Res 1373, UN Doc S/Res/1373 (28 September 2001).

Katie King, Naz K Modirzadeh and Dustin A Lewis, Understanding Humanitarian Exemptions: UN Security Council Sanctions and Principled Humanitarian Action: Working Group Briefing Memorandum (Harvard Law School Program on International Law and Armed Conflict Counterterrorism and Humanitarian Engagement Project, April 2016) 4 <http://blogs.harvard.edu/pilac/files/2016/04/ Understanding_Humanitarian_Exemptions_April_2016.pdf $>$.

For an overview of the impact of counter-terrorism measures on humanitarian action, see: Kate Mackintosh and Patrick Duplat, Study of the Impact of Donor Counter-Terrorism Measures on Principled Humanitarian Action (OCHA, July 2013); Phoebe Wynn-Pope, Yvette Zegenhagen and 
An increasing number of belligerent states are denying or restricting the operation of humanitarian relief efforts on their territory under the guise of counter-terrorism, arguing that terrorist groups are manipulating humanitarian activities to fund their campaigns. ${ }^{98}$ Where domestic counter-terrorism measures criminalise any support provided to terrorist groups, humanitarian organisations may face criminal prosecution. ${ }^{99}$ However, the criminalisation of humanitarian assistance in these circumstances would be incompatible with the legal framework governing humanitarian assistance and the fundamental principles espoused within this framework. ${ }^{100}$ In particular, humane treatment must be accorded to all victims, with priority only given to 'the most urgent cases of distress', ${ }^{101}$ and adverse distinctions cannot be drawn with respect to ideology or criminality. ${ }^{102}$ However, where counter-terrorism laws designate certain groups as terrorist and criminalise interactions with these groups, it contributes to a hierarchy of deserving victims. ${ }^{103}$ Additionally, in circumstances where a state's counter-terrorism legalisation specifically directs humanitarian actors away from providing assistance to a 'terrorist group', the principles of impartiality and neutrality will likewise be compromised. ${ }^{104}$ On the contrary, where humanitarian actors are provided with the ability to engage with all sides to the conflict, the principle of impartiality will be easier to meet and neutrality can be maintained. ${ }^{105}$ Furthermore, where humanitarian actors make principled offers of assistance to civilians under the effective control of a non-state armed group designated as a terrorist group, the state is prohibited under international humanitarian law from rejecting such offers where the effect or intention of withholding consent is to discriminate against sections of the population because they support the terrorist group. ${ }^{106}$ This would not only be contrary to the principle of non-distinction but could also amount to the crime against humanity of persecution if the

Fauve Kurnadi, 'Legislating against Humanitarian Principles: A Case Study on the Humanitarian Implications of Australian Counterterrorism Legislation' (2016) 97(897/898) International Review of the Red Cross 235; Ben Saul, 'Terrorism, Counter-Terrorism and Humanitarian Law' (Legal Studies Research Paper No 16/37, Sydney Law School, 2016) 15. Claudia McGoldrick, 'The Future of Humanitarian Action: An ICRC Perspective' (2011) 93(884) International Review of the Red Cross 965, 973. Burniske and Modirzadeh (n 4) 629-30.

100 ICRC, 'International Humanitarian Law and the Challenges of Contemporary Armed Conflict' (31 ${ }^{\text {st }}$ International Conference of the Red Cross and Red Crescent, Geneva 28 November-1 December 2011) 52 ('ICRC Conference 2011').

The principle of impartiality is a fundamental principle of the ICRC see Pictet (n 22) 197, 257 and was endorsed by the IJC in Nicaragua (n 10) 114-5 [242]. 30) 17 .

103 Saul (n 97) 17

$104 \quad$ ICRC Conference 2011 (n 100) 52.

105 Burniske and Modirzadeh (n 4) 642.

106 Akande and Gillard (n 56) 24. 
discriminatory conduct is committed in connection with another international crime. ${ }^{107}$ Likewise, withholding consent to punish the civilian population for terrorist acts committed by the non-state armed group, for which the former are not responsible, would violate the prohibition on collective punishment. ${ }^{108}$

It is argued that domestic counter-terrorism measures challenge the perceived neutrality and impartiality of humanitarian actors, particularly in situations where the latter is reliant on a designated terrorist group to provide security or is required to engage with them to facilitate access. ${ }^{109}$ However, mere engagement with a non-state armed group listed as a terrorist organisation in order to facilitate the provision of humanitarian aid to civilians within its effective control will not deprive a humanitarian actor of its neutrality; ${ }^{110}$ nor can it be conceived as an unfriendly act or as an endorsement of that party's plight. ${ }^{111} \mathrm{As}$ long as, in working to secure and sustain humanitarian access, its actions are guided only by the alleviation of human suffering rather than the furtherance of the political, religious or ideological views of the party, or otherwise supporting its efforts, the aid will meet the neutrality requirements. ${ }^{112}$ However, humanitarian aid should not provide one side to the conflict with a definite military advantage. ${ }^{113}$ Where the non-state armed group or terrorist organisation is diverting relief to fund their military campaign, the neutrality of the aid may be compromised and will potentially give the state a legitimate reason to withhold consent. ${ }^{114}$

Questions invariably arise as to who is the appropriate actor to determine whether a non-state armed group is diverting relief for its own benefit and, furthermore, what proportion of relief needs to be diverted for the denial of consent to be lawful. Such assessments will necessarily involve balancing the humanitarian plight of civilians with the state's legitimate concerns that the enemy does not receive a definite military advantage - that aid is not channelled into the hands of terrorists or otherwise enables the group to commit more funds to terrorist activities. ${ }^{115}$ How such assessments are made will depend on the particular factual circumstances, but they should not be left to the discretion of the state. Rather, humanitarian actors must retain operational control when

Rome Statute of the International Criminal Court (adopted 17 July 1998, entered into force 1 July 2002) 2187 UNTS 3, art 7(1)(b).

AP II, art 4(2)(b).

Wynn-Pope et al (n 97) 257-8.

ICRC Conference 2011 (n 100) 52-3.

Commentary on the First Geneva Convention 2016 (n 21) 804-5.

Ibid 12; Stoffels (n 25) 542-4; Mackintosh and Duplat (n 97) 12.

The ICRC Commentary with respect to international armed conflicts acknowledges that the receiving party will receive some benefit from the receipt of humanitarian assistance, but any benefit must not be so great so as to improve that party's economic or military position: Jean S Pictet (ed), Commentary on Geneva Convention IV of 12 August 1949 (ICRC, 1958) 182.

Gillard (n 55) 367 and Ryngaert (n 62) 9.

Ryngaert (n 62) 9. 
securing and sustaining humanitarian access. Where control is lost, the humanitarian actor should withdraw its offer of aid, as its perceived neutrality may be lost.

\section{The COVID-19 Pandemic and Consent to Humanitarian Assistance}

On 11 March 2020, the World Health Organization declared the COVID-19 virus to be a global pandemic. In response, many states implemented emergency health measures to suppress and mitigate its spread, including banning international flights, closing borders, prohibiting social gatherings, restricting movement, and imposing countrywide lockdowns and curfews. However, measures implemented in response to COVID-19 restricting the cross-border movement of foreign workers and essential supplies have placed constraints on the operational capacity of humanitarian workers to provide aid, while social-distancing measures, lockdowns and curfews have obstructed populations from accessing aid. ${ }^{116}$ Whether a pandemic, such as COVID-19, can provide states with the ability to legally withhold their consent to humanitarian aid involves drawing a balance between, on the one hand, the duty of the state to protect public health and control the spread of a disease and, on the other hand, its duty to provide or otherwise allow for the provision of essential services to its population.

Withholding consent to humanitarian aid is not unreasonable where ostensibly pursuing a legitimate objective, such as military necessity or protecting public health. ${ }^{117}$ However, consent should not be withheld beyond that which is necessary and proportionate. ${ }^{118}$ This requires striking a balancing between the legitimate objective of protecting public health and the competing humanitarian imperative to assist those in need. While measures to mitigate the devastating impacts of COVID-19 are necessary for populations in armed conflicts, ${ }^{119}$ much like the case of military necessity, denials of consent on the basis of public health must only be temporary and limited. ${ }^{120}$ This may include, for example, quarantine requirements for international arrivals. However, where the withholding of consent goes beyond this and compounds the consequent

See Human Rights Watch (n 7); OCHA (n 8); Human Rights Watch, 'Deadly Consequences: Obstruction of Aid in Yemen During Covid-19' (Human Rights Watch, 2020) <https://www.hrw.org/report/2020/09/14/deadly-consequences/obstruction-aid-yemenduring-covid-19>.

Akande and Gillard (n 56) 24.

Ibid.

UN Covid-19 Press Release (n 6).

ICRC Customary Law Study (n 42) 202, r 56. 
suffering of the population it will amount to a violation of the state's international legal obligations and will be arbitrary. This is the position of the ICRC. ${ }^{121}$

This does not undermine the right of the state to exert control over relief efforts occurring on its territory. ${ }^{122}$ This could include regulating activities in accordance with domestic laws and regulations with respect to public health and safety, such as the mandating of masks or introducing alternative methods of delivering assistance to ensure that social distancing is observed. However, states must not use public-health restrictions as a means of covertly inhibiting the passage of humanitarian operations through unnecessary delays or otherwise impeding their implementation. ${ }^{123}$ Where such measures amount in practice to a refusal of consent, they will be arbitrary and incompatible with international humanitarian law.

\section{ENForcing THE Right to HumanitaRian Assistance}

The civilian population has a right to receive humanitarian assistance essential for its survival. This rule exists in customary law in both international and noninternational conflicts. ${ }^{124}$ It is derived implicitly from Article 18(2), which requires that relief operations 'shall be undertaken' whenever the civilian population is in need. ${ }^{125}$ The state has the primary responsibility to fulfill this right. ${ }^{126}$ Where the state is unwilling or unable to do so itself, it must permit and facilitate the unimpeded passage of relief operations on its territory. ${ }^{127}$ There is increasing acceptance that non-state armed groups also have obligations under international humanitarian law to treat the population under their control humanely. This includes ensuring the safe and rapid passage of humanitarian aid and the protection of humanitarian personnel. ${ }^{128}$ The right of impartial humanitarian organisations, including the ICRC and private actors, to offer their services to the 'parties to the conflict' does not, however, equate to a right to provide assistance, as the requirement of state consent and primacy of territorial

\footnotetext{
121 ICRC, 'IHL Rules on Humanitarian Access and Covid-19' (Press Release, 8 April 2020) 3.

122 ICRC Customary Law Study (n 42) 193, r 55.

123 ICRC, 'IHL Rules on Humanitarian Access and Covid-19' (n 121) 3.

124 ICRC Customary Law Study (n 42) 199, r 55.

125 Ibid.

126 Sandoz et al (n 40) 4871 and 4878; ICRC, 'Q\&A and Lexicon on Humanitarian Access' (n 11) 363, 4871; Commentary on the First Geneva Convention 2016 (n 21) 782 and GA Res 45/100, UN Doc A/RES/45/100 (14 December 1990) Preamble; GA Res 46/182 (n 17) [4]; ICRC, 'Q\&A and Lexicon on Humanitarian Access' ( $n$ 11) 363: this 'can be inferred [in non-international armed conflict] from the object and purpose of international humanitarian law'.

127 ICRC Customary Law Study (n 42) 196-7, r 55.

128 See, eg, SC Res 1894 (n 17) [14]; SC Res 1923 (n 57) [22]; SC Res 2191, S/RES/2191 (17 December 2014) Preamble, [1].
} 
sovereignty in international law impose significant barriers with respect to the enforcement of this right. ${ }^{229}$ Even where consent is arbitrarily withheld by the state, humanitarian actors do not have a general right of access under the Geneva Conventions.

It has been proposed that a rule of customary law has emerged in such circumstances, dispensing with the requirement of consent and allowing aid to be delivered into territory held by the non-state armed group. ${ }^{130}$ Under this rule, cross-border operations would be lawful when the following conditions are met: aid is intended for civilians in territory under the effective control of a non-state armed group; it can be delivered by bypassing the territory of the state; the state has arbitrarily withheld its consent to such an operation; and the relief operation meets the requirements of neutrality, impartiality and humanity. ${ }^{131}$ Such a rule was not identified in the 2005 ICRC Study in Customary International Law, which subjects the provision of relief to the consent of the state. ${ }^{132}$ However, a number of commentators have argued that since the completion of this study there is sufficient international consensus, strengthened by state practice, General Assembly and Security Council Resolutions, which suggests that the requirement of consent is weakening. ${ }^{133}$ In particular, as evidence that an international norm is developing that supports the legality of cross-border operations, commentators have pointed to a number of General Assembly and Security Council resolutions obliging parties to facilitate access and respect the safe and unhindered passage of humanitarian personnel, the lack of international responses to unauthorised aid operations, and the international condemnation by states of parties that fail to allow or facilitate humanitarian access. ${ }^{134}$

However, state practice in conformity with the alleged rule allowing or supporting relief operations without prior consent has not been universal or

Commentary on the First Geneva Convention 2016 (n 21) 828; Sandoz et al (n 40) 4883; The Case of the SS Lotus (France v Turkey) [1927] PCIJ Series A No 9, [18].

See Stoffels (n 25) 536; Gillard (n 55); Ryngaert (n 62) 13; Alex J Bellamy, 'Opening the Door to Humanitarian Aid in Syria: Significance, Challenges, and Prospects' (The Global Observatory, 17 July 2014) <https://theglobalobservatory.org/2014/07/opening-door-humanitarian-aid-insyria-significance-challenges-prospects/>; Tilman Rodenhäuser and Jonathan Somer, 'The Security Council and Humanitarian Relief Operations in Opposition-Held Territories' (EJIL Talk, 12 August 2014) <https://www.ejiltalk.org/the-security-council-and-humanitarian-relief-inopposition-held-territories/>; Naz Modirzadeh, 'Strong Words, Weak Arguments - A Response to the Open Letter to the UN on Humanitarian Access to Syria (Part 1)' (OpinoJuris, 12 May 2014) <http://opiniojuris.org/2014/05/12/guest-post-strong-words-weak-arguments-responseopen-letter-un-humanitarian-access-syria-part-1/>

Akhavan et al (n 48).

ICRC Customary Law Study (n 42) 196-7.

Rebecca Barber, 'Facilitating Humanitarian Assistance in International Humanitarian and Human Rights Law' (2009) 91(874) International Review of the Red Cross 371, 389; Stoffels (n 25) 536; Akhavan et al (n 48); Sassoli (n 48) and Bothe (n 52) 801.

Barber (n 133) 390-1; Stoffels (n 25) 356. 
adequate. ${ }^{135}$ Importantly, states that have been the subject of such resolutions, and are therefore specifically affected, have not consistently adhered to the obligations to allow and facilitate access as directed. ${ }^{136}$ Furthermore, while General Assembly resolutions have called for parties to facilitate access, ${ }^{137}$ they do not go as far as proclaiming a general right of access and remain framed around the mandatory requirement of state consent. ${ }^{138}$ Likewise, although the wording of successive Security Council resolutions have moved from reaffirming the obligation of parties to facilitate humanitarian access, to demanding that parties allow access, ${ }^{139}$ they continue to reiterate the sovereignty and territorial integrity of the state concerned..$^{140}$ The ICRC has also maintained its position that all humanitarian operations must accord with the provisions of international humanitarian law, including the requirement of consent, and only once consent is obtained does the requirement to facilitate access arise. ${ }^{141}$

Whether the customary status of cross-border relief operations crystalised with the adoption by the Security Council of Resolution 2165, which required parties to the Syrian conflict to allow access without the prior consent of the government, is also contentious. First, the Security Council did not articulate or affirm a general right of access in Syria; rather, the right of access stemmed from the specific authorisation of the Security Council. ${ }^{142}$ The lack of a general right is further reinforced by the fact that the initial resolution was limited to a period of 180 days and to UN humanitarian agencies and their implementing partners. ${ }^{143}$ If the Security Council had intended a general right of access without Syrian government consent, it arguably would have extended the right to deliver aid cross-border to all humanitarian actors for an unlimited period of time.144 Secondly, Resolution 2165 does not seek to interpret or challenge the rules of international humanitarian law regarding humanitarian assistance. Rather, the source of authority exercised by UN humanitarian agencies and their partners to

Ryngaert (n 62) 13; Spieker (n 12); Kuijt (n 12) 333; Modirzadeh n 131.

For examples, see Barber (n 133) 390. See also Report of the Secretary-General on the implementation of Security Council Resolutions 2139 (2014), 2165 (2014), 2191 (2014), 2258 (2015), 2332 (2016), 2393 (2017) and 2401 (2018) UN Doc S/2018/724 (20 July 2018) [38] ('Report of the Secretary-General $\left.2018^{\prime}\right)$.

GA Res 46/182 (n 17) [4]; GA Res 52/167, A/Res/52/167 (18 February 1998) [3] and GA Res 69/135, A/Res/69/135 (19 January 2015) [49].

Spieker (n 12).

SC Res 1894 (n 17) [4]; SC Res 1923 (n 57) Preamble; cf SC Res 2127, UN Doc S/RES/2127 (5 December 2013) [52] and SC Res 2139 (n 81) [6].

UNSC Res 1894 (n 17) Preamble; SC Res 2127 (n 139) Preamble; SC Res 2139 (n 81) Preamble.

ICRC, 'Q\&A and Lexicon on Humanitarian Access' (n 11) 362.

Bellamy (n 130).

Operative paragraphs [2] and [3] of Security Council Resolution 2165 were renewed annually from 2015 to 2018 for periods of 12 months. They have not been extended past January 2020.

Zimmermann (n 71) 18. 
deliver humanitarian assistance without consent lies in binding decisions of the Security Council..$^{145}$ Finally, all parties to the Syrian conflict continue to obstruct humanitarian assistance and consequently, access across conflict lines remains limited. ${ }^{146}$ This again demonstrates that state practice, particularly by states specifically affected, is not uniform. Thus, while the Security Council's demands are binding on the parties to the conflict in Syria, it is premature to speak of the existence of a general customary norm allowing humanitarian actors to operate without state consent or Security Council authorisation.

As the law currently stands, international humanitarian law does not allow for a right of humanitarian relief without the consent of the territorial state, even when relief operations are intended for civilians under the effective control of a non-state armed group. However, this does not mean that the international community is powerless to act. Such operations may be legal where the source of their authority is derived from an alternative rule of international law allowing such action, for example, a binding decision of the Security Council or, alternatively, the rules of state responsibility, which are discussed below.

\section{A Right of Access and the Rules of State Responsibility}

The impediment of relief operations by the belligerent state is a violation of international humanitarian law, which activates the rules of state responsibility. ${ }^{147}$ While a breach by the state does not automatically entitle the international community to conduct relief operations without consent, the wrongfulness of such action may nonetheless be precluded as a lawful countermeasure, or otherwise by the principle of necessity. ${ }^{148}$ These exemptions are only applicable in a restricted number of circumstances and are subject to strict limitations. However, they arguably provide the only avenue to circumvent the supremacy of state sovereignty and allow for the provision of humanitarian assistance to civilians in need.

Humanitarian relief operations carried out without state consent may be justified by the principle of necessity in circumstances where such action is necessary to 'safeguard an essential interest' of the state, or of the international

145 Rodenhauser and Somer (n 130).

146 Report of the Secretary-General 2018 (n 136) [38].

147 International Law Commission, Draft Articles on the Responsibility of States for Intentionally Wrongful Acts, with Commentaries (2001) UN Doc A/56/10, art 1 ('Commentary to ARSIWA'). There is a general consensus that ARSIWA largely reflects customary international law. See James Crawford, State Responsibility: The General Part (Cambridge University Press, 2013) 43. 
community as a whole. ${ }^{149}$ The grave and imminent suffering or starvation of the civilian population may be considered an essential interest of the international community. ${ }^{150}$ To rely on the doctrine of necessity, the unlawful relief operation must be the only (lawful) way to safeguard this interest. ${ }^{151}$ Furthermore, it must not seriously impair the territorial sovereignty of the state, or otherwise amount to forcible humanitarian intervention. ${ }^{152}$ Where the territorial incursion is temporary - for example, one-off airdrops of life-saving supplies - and the civilian population would otherwise starve, the violation of the state's territorial integrity will arguably not be seriously impaired. ${ }^{153}$ Accordingly, where unlawful unilateral relief operations are the only way to deliver life-saving supplies to safeguard the civilian population from a grave and imminent peril and their scope is temporary, they may be permitted under the doctrine of necessity. ${ }^{154}$

Alternatively, relief operations conducted without the consent of the state may constitute lawful countermeasures, justifying an otherwise unlawful relief operation. ${ }^{155}$ First, relief operations conducted without consent must be temporary ${ }^{156}$ and proportionate to the injury suffered. ${ }^{157}$ Given that relief operations will violate the state's territorial sovereignty, it must be shown that the failure to consent to relief operations amounted to a serious breach of international law. ${ }^{158}$ This will most likely only be established in extreme cases, such as the starvation of the population. ${ }^{159}$ Secondly, countermeasures must not amount to an act of reprisal violating the prohibition against the use of force or the rules of international humanitarian law. ${ }^{160}$ Thirdly, the purpose of the operation must be to induce the violating state to comply with its international legal obligations. ${ }^{161}$ Arguably, where a humanitarian actor carries out relief operations, the state's duty is fulfilled. ${ }^{162}$ However, where the aim is to draw attention to and compel the state to cease its breaches of international law and provide or allow humanitarian assistance, such action will arguably be lawful as

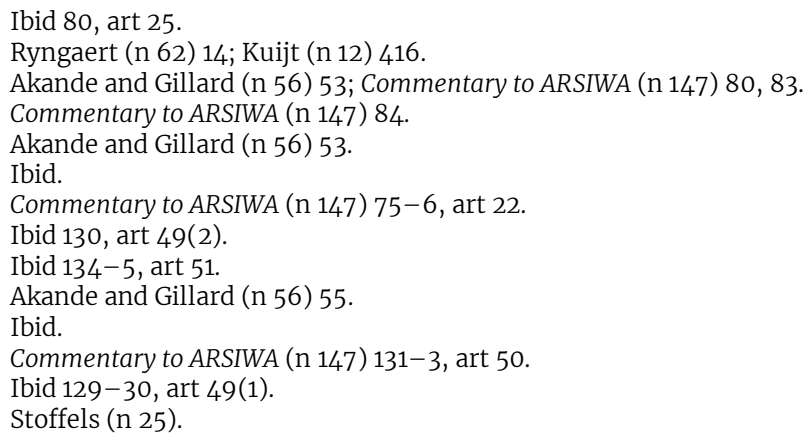


long as any measures undertaken cease once the state provides or allows humanitarian assistance. ${ }^{163}$

While a state can generally only take countermeasures when it was directly injured by the wrongful act, ${ }^{164}$ non-injured states can invoke the responsibility of the defaulting state and claim cessation and guarantees of non-repetition when there has been a breach of an obligation owed to the international community as a whole. ${ }^{165}$ It is unclear whether a non-injured state can also undertake countermeasures in the collective interest to compel compliance. ${ }^{166}$ The International Law Commission ('ILC'), in its Commentary to the Articles on the Responsibility of States for Intentionally Wrongful Acts ('ARSIWA'), cited some examples whereby states that could not be considered injured in the sense of Article 42 of ARSIWA had initiated economic sanctions or other similar measures in response to violations of erga omnes obligations. ${ }^{167}$ However, the ILC noted that such a practice was 'limited and rather embryotic'. ${ }^{168}$ As it stands, therefore, current state practice and opinio juris is not sufficiently widespread and consistent to establish a rule allowing non-injured states to undertake countermeasures in the collective interest where an erga omnes obligation is violated, particularly where a countermeasure would infringe the territorial sovereignty of a state. ${ }^{169}$ On this basis, unlawful relief operations would not be justifiable as a countermeasure in accordance with the rules of state responsibility. However, if a state is injured within the meaning of Article 42 of ARSIWA, it can undertake countermeasures ${ }^{170}$ and potentially conduct unilateral relief operations without consent. To meet the criteria in Article 42, the injured state must be specifically affected by the breach of an obligation owed to the international community as a whole. ${ }^{171}$ The obligation to allow and facilitate humanitarian access is arguably an obligation owed to the international community as a whole, particularly in circumstances where its violation leads to a humanitarian crisis or large-scale human rights violations, or amounts to a threat to or breach of the peace. ${ }^{172}$ For a state to show that it is injured it must demonstrate that the belligerent state's failure to consent to humanitarian relief operations has caused adverse affects on its territory. For example, a humanitarian crisis created by a failure to allow or facilitate humanitarian relief may lead to the movement of refugees into the

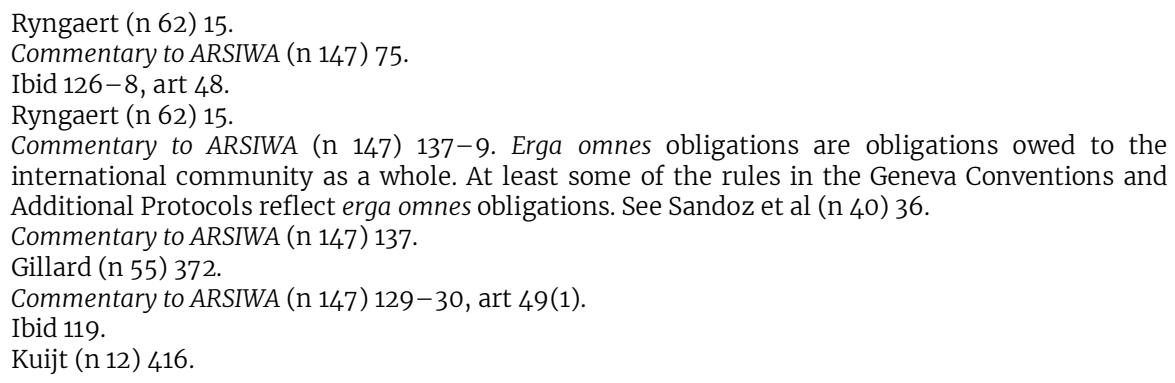


territory of neighboring states, causing competition for already scarce resources, adversely affecting the latter. However, it may be in such circumstances difficult to justify countermeasures in practice. If a state has the means to provide external relief operations, it arguably has sufficient resources to support refugees within its borders and can therefore take steps to remedy the humanitarian crisis without breaching the territorial sovereignty of the belligerent state. As such, the likelihood of a state fulfilling the criteria in Article 42 is minimal, and it will be difficult to justify an unlawful relief operation as a legitimate countermeasure.

\section{CONCLUSION}

Humanitarian assistance is essential to reducing the suffering of civilians affected by armed conflicts. However, its regulation in international law involves drawing a balance between the right of the state to its territorial sovereignty, the right of victims to receive essential supplies, and the interest of the international community in enforcing this right. These competing rights and interests are not easily reconciled, as the consensual basis of international law has traditionally been privileged. However, there is growing recognition within the international community that the freedom of states is not unlimited and its conduct towards its own citizens is increasingly a matter of international concern. This has contributed to the formation of a customary rule prohibiting states from arbitrarily withholding consent to humanitarian operations in both international and non-international armed conflicts, including where relief is intended for a non-state armed group or a designated terrorist group. Where a state arbitrarily withholds consent, it will constitute a violation of international law.

However, the trajectory of international law with respect to humanitarian assistance has focused on what amounts to an arbitrary withholding of consent, rather than eliminating the requirement to obtain consent. Despite some arguments to the contrary, the requirement of consent in the Geneva Conventions and Additional Protocols remains a constriction on the provision of aid and state practice, and opinio juris has not evolved sufficiently so as to allow for an unfettered right of access into opposition-held territory without state consent. However, while unilateral humanitarian operations conducted without state consent will not be protected under international humanitarian law, where its legality is derived from another source of international law, namely, a biding decision of the Security Council or the rules of state responsibility, an otherwise unlawful relief operation may be permissible. Outside of those limited options, the lack of effective mechanisms to implement and enforce impartial humanitarian operations means that the right of civilians to receive assistance often remains illusory. It is therefore imperative that the international community continues to pressure belligerent parties to abide by their legal obligations to ensure that the needs of civilians are adequately met. 
